\title{
Interactive comment on "Coccolithophore responses to environmental variability in the South China Sea: species composition and calcite content" by X. B. Jin et al.
}

\author{
X. B. Jin et al. \\ 386jinxiaobo@tongji.edu.cn \\ Received and published: 12 April 2016
}

[This manuscript shows composition of coccolithophores and contribution of each coccolithophore species/taxa to the calcite suspension in the water column in the South China Sea. Results from this study are useful for understanding of coccolithophore ïńĆra in the marginal sea. I would recommend publish this manuscript from the Biogeosciences after major revision. My comments are as follows]

We would like to thank the reviewer for the helpful comments to improve the discussion paper.

[Page 4 Line 1; 'Gladiolithus, Calciosolenia and Algirosphaera' are coccolithophore 
genus not coccolith species.]

Reply: 'species' has been revised as 'genera'.

[Page 6 Line 4, Page 8 Line 34, Page 8 Line 40; Three taxa not three species, since 'Gephyrocapsa spp.' includes multiple species.]

Reply: 'species' has been revised as 'taxa'.

[Page 6 Line 6. and Figure 7; Authors mixed the coccoliths of Gephyrocapsa ericsonii and of Gephyrocapsa oceanica into a same category, Gephyrocapsa spp. in the estimation of calcite content, despite the volume/size of coccoliths of $\mathrm{G}$. ericsonii is signiïñ Ącantly smaller than that of $\mathrm{G}$. oceanica. I would recommend authors to separate these two species from each other in the estimation of calcite content, revise Figure 7 with new estimation, and make discussion based on the new estimation.]

Reply: Although in water column, the two species of Gephyrocapsa (G. oceanica and G. ericsonii) contributed similar cell population to Gephyrocapsa standing crops in coccolithophore ecological groups (Table 2), G. oceanica was the main contributor to Gephyrocapsa calcite inventory. For example G. oceanica and G. ericsonii comprised $7.00 \%$ and $0.87 \%$ (totally $7.87 \%$, on average) of total calcite concentration, respectively. Figure 7 has been redrawn with estimation of these two species (Figure 7: The relative contribution of E. huxleyi (a), F. profunda (b), G. oceanica (c) and G. ericsonii (d) to total coccolithophore-based calcite concentration in water column. The black coarse lines denote moving average of 30 grid-points.). And we have supplemented the new estimation and discussion into relevant sections. (see red words in attached file)

[Page 6 Lines 32-33; "The coccolithophore assemblages of the SCS are similar with those in the equatorial Paciï̌Ac Ocean (Hagino et al., 2000)." Hagino et al. (2000) reported variation in coccolithophore assemblages in the equatorial PaciïñĄ. Which of the Hagino's assemblages resembles to the assemblage observed in this study?]

Printer-friendly version

Discussion paper 
Reply: We agree with the comment of the reviewer. In Hagino et al. (2000), coccolithophore florae are divided into four assemblages: High Temperature, Warm Oligotrophic, Warm Eutrophic and Temperature mixed-water. Coccolithophore taxa observed in the South China Sea resemble "High Temperature" and "Warm Oligotrophic" assemblages which include (ecological groups): UPG (U. irregularis, D. tubifera), LPG (F. profunda, A. robasta, G. flabellatus) and OPG (E. huxleyi). Hence, it has been rewritten as "The coccolithophore florae of the SCS are similar with 'High Temperature' and 'Warm Oligotrophic' assemblages in the equatorial Paciïñ̨c Ocean (Hagino et al., 2000)."

[Page 6 Lines 35-37; "However, in the equatorial and subtropical gyres of the PaciïňAc and Atlantic Ocean, these coccolithophore species are found much deeper $(150 \mathrm{~m}$ to $250 \mathrm{~m}$ ) in the water column (Hagino et al., 2000; Boeckel and Baumann, 2008; Beaufort et al., 2008)." Hagino et al. (2000) studied coccolithophore assemblages in the equatorial upwelling front and in the Western Paciïñ c Warm Pool, not in the gyre. By the way, what is the 'equatorial gyre'?]

Reply: Apologizing for the vague description, here we meant coccolithophores in the West Pacific Warm Pool (stratified water, not mixed water and upwelling region) studied by Hagino et al. (2000), the subtropical gyre of the Pacific (by Beaufort et al., 2008) and of the Atlantic (by Boeckel and Baumann, 2008). The sentence has been rephrased that "However, in the West Pacifica Warm Pool (stratified waters) and subtropical gyres of the Paciïñ Ac and Atlantic Ocean, species F. profunda are found much deeper (150 $\mathrm{m}$ to $250 \mathrm{~m}$ ) in the water column (Hagino et al., 2000; Boeckel and Baumann, 2008; Beaufort et al., 2008)."

[Page 7 Line 1; "Group 1 included umbelliform species, such as U. irregularis, which are considered K-selected (specialists) species" Please cite some papers that mentioned $\mathrm{U}$. irregularis as K-selected species.]

Reply: reference added: 'Young, 1994. Functions of coccoliths. In Coccolithophores,

Printer-friendly version

Discussion paper 
edited by Winter, A. and Siesser, W.G., Cambridge University Press.'

Please also note the supplement to this comment:

http://www.biogeosciences-discuss.net/bg-2016-77/bg-2016-77-AC1-supplement.pdf

Interactive comment on Biogeosciences Discuss., doi:10.5194/bg-2016-77, 2016. 

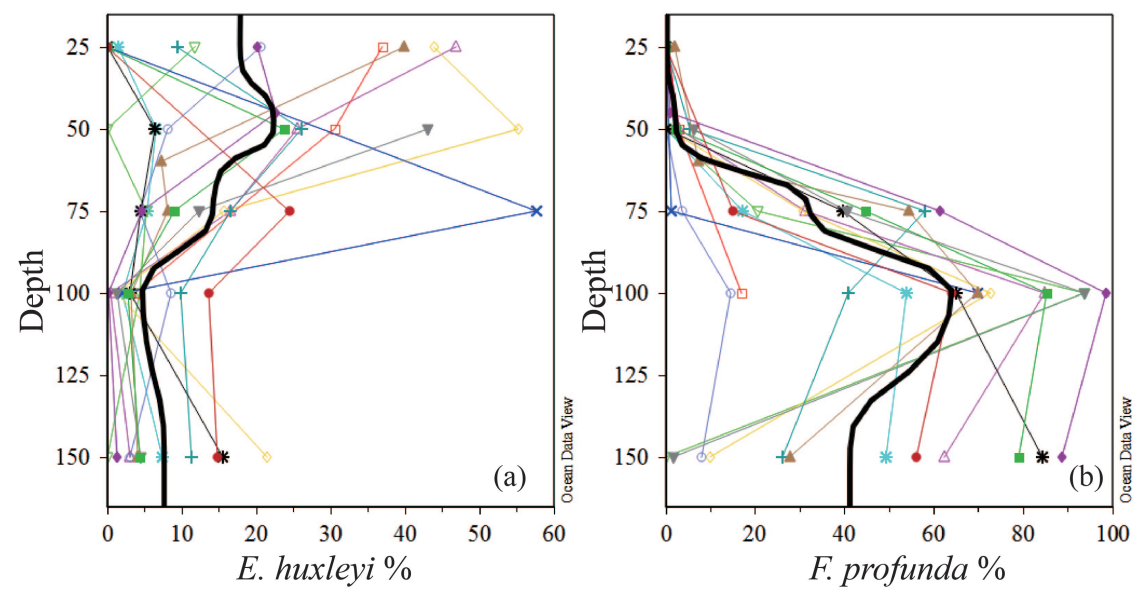

BGD
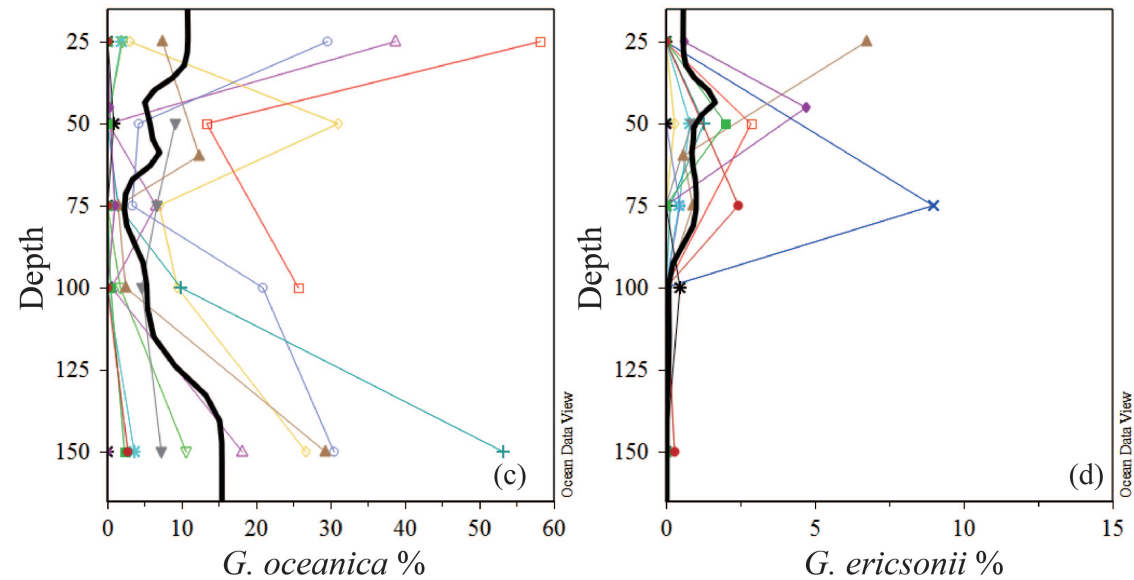

Interactive

comment

Printer-friendly version

Fig. 1. Figure 7

Discussion paper 